\title{
Comparing the Outcomes of Children of Same-Sex and Opposite-Sex Partners: Overview of the Quantitative Studies Conducted on Random Representative Samples*
}

\author{
Tanja VUČKOVIĆ JUROŠ \\ Interdisciplinary Research Center on Families and Sexualities (CIRFASE), University of \\ Louvain (UCL), Louvain-la-Neuve, Belgium \\ tanja.vuckovic@uclouvain.be
}

\begin{abstract}
The research on homoparentality started in the late 1970s and early 1980s in the AngloSaxon context. A great majority of those studies found no evidence of harmful outcomes for the children of lesbians and gays resulting from their parents' sexual orientation. Those studies, however, were typically limited by small-size samples and restricted to the analysis of lesbian families. Quantitative studies comparing the outcomes of children from different family structures based on random representative samples have been conducted since the beginning of the 21 st century. The present paper systematically reviews that research by focusing on three points of methodological debate identified in the literature on homoparentality: sample characteristics, operationalisation of the category of same-sex partners' children, and the inclusion of the control for family stability. The results of most quantitative studies based on random representative samples were consistent with the findings of the previous studies. The minority of those studies that did find some differences in harmful outcomes between the children of same-sex and opposite-sex partners were characterised by serious methodological flaws. They ranged from artificially inflating the category of the children of same-sex parents (for instance, by including children who were possibly or probably never raised by a same-sex couple) to omitting a control variable of family stability from the analyses. Therefore, this review concludes that scientifically the most credible quantitative studies support the conclusions of numerous earlier qualitative and quantitative studies conducted using convenience samples - there is no credible evidence that the children raised by same-sex partners fare worse than the children of opposite-sex partners due to the sexual orientation of their parents.
\end{abstract}

Key words: children, well-being of children, harmful outcomes of upbringing, family, same-sex partners, opposite-sex partners, homoparentality

\footnotetext{
*This translation is authorized by author and publisher. It was made possible by funding through Marie Skłodowska-Curie Individual Fellowship \#702650. Citations should reference the original article: Vučković Juroš, Tanja (2017). "Usporedba ishoda djece iz obitelji istospolnih i raznospolnih partnera: osvrt na kvantitativne studije provedene na slučajnim reprezentativnim uzorcima [Comparing the Outcomes of Children of Same-Sex and Opposite-Sex Partners: Overview of the Quantitative Studies Conducted on Random Representative Samples]", Revija za sociologiju, 47 (1): 65-95, doi: 10.5613/rzs.47.1.3.
} 


\section{Introduction}

Lesbian and gay families have been getting more and more attention from both the scientific community and a wider audience ${ }^{1}$. The expansion of the rights of LGBT individuals in numerous western countries has made the issue of same-sex marriages and same-sex couples' right to have children a current political issue. Simultaneously, research on different aspects of homoparentality has made a major breakthrough, most notably by comparing the outcomes of children raised by samesex partners with children raised by opposite-sex (heterosexual) partners. This topic, indeed, has been of the greatest interest to the general public that has been questioning whether the children of lesbian mothers, gay fathers or children raised by same-sex couples are in a less favourable position compared to children of parents identifying as heterosexuals. Scientific studies of varying quality and media exposure have attempted to provide answers to these questions. Quantitative studies conducted on large samples have garnered the most attention. However, the conclusions of some of these studies have often been presented to the public uncritically (e.g. Jarić Dauenhauer, 2013). In those cases, the sample size was often equated with the quality of the study while all other characteristics relevant for the evaluation of the study's results and interpretations were neglected. Therefore, this critical review has examined the studies that garnered the most media attention quantitative studies conducted on large random samples which compared outcomes of children coming from families of same- and opposite-sex partners. In the text that follows, I have systematically presented their strengths and weaknesses.

In scientific literature, one can find a large number of review articles on homoparentality which evaluate the conclusions of different studies and attempt to assess whether there exists a scientific consensus about the outcomes of lesbian and gay parenting. Looking only at those papers published since 2010, those topics have been discussed in respectable scientific journals (Biblarz and Savci, 2010; Marks, 2012; Moore and Stambolis-Ruhstorfer, 2013; Manning, Fettro and Lamidi, 2014; Allen, 2015; Fedwa, Black and Ahn, 2015), in books from reputable publishers (Lubbe, 2013; 2013; Biblarz, Carroll and Burke, 2014) and in reports by professional organizations, academic institutions and brain trusts (American

\footnotetext{
${ }^{1}$ In the literature, the term LGBT family is often used to refer to families of lesbian, gay, bisexual, transgender and transsexual individuals. However, the existing research has focused mostly on lesbians and gays. Therefore, in this text I have used the terms lesbian mother and gay father or same-sex couple/partners, regardless of sexual orientation and gender identification of the individuals in such families. Even though there are also children raised by parents who identify as, for example, bisexual or transgender, researchers have rarely examined this group, nor have they explicitly analysed the sexual and gender identification of parents in general. Although this is, of course, a narrow perspective on homoparentality, I am obliged to follow it in this paper as well.
} 
Sociological Association, 2015; Gates, 2015). Nevertheless, the existing review articles typically provide a wider overview of the area in question, or focus on some isolated characteristics of particular research projects. Based on this literature, therefore, it is difficult to systematically identify all points of debate and to consistently compare controversial points for all studies in a category.

This paper provides one such systematic comparison of all the quantitative studies conducted on large random samples which have been published in peerreviewed journals before February 2017. Some of the studies included in this analysis, those published after 2015, have never before been reviewed. I used the insights from existing review articles to identify three main points used for evaluation of the validity of these published case studies: sample characteristics, operationalisation of the children-of-same-sex-partners category, and inclusion of a control variable for family stability. I have systematically analysed these three points for each and every study included. As a result, this paper provides a comprehensive overview of specific methodological questions which are key to interpreting results about the outcomes of children of same- and opposite-sex partners. This allows the interested readers to assess for themselves the validity of the arguments and the quality of the individual studies.

I have analysed solely those quantitative studies that were conducted on random representative samples and that compared academic and psychosocial outcomes of children of same- and opposite-sex parents. As it will be argued in more detail later, this focus does not imply that the studies that did not belong to this type are less valuable. On the contrary, qualitative studies, for example, provided a considerable insight into issues of homoparentality. Likewise, under certain conditions, even some quantitative studies conducted on non-probabilistic samples provided valuable findings. Nevertheless, the studies of homoparentality on large random samples, that started to be conducted in the early 21 st century, are of the greatest interest because they explicitly include children from families of same-sex parents and thus provide a new understanding of the outcomes of these children. Next, the outcomes I have considered in this analysis were limited to those that can be interpreted as harmful for children, and which are, therefore, most controversial for the general public. Most often, this included academic outcomes (grade retention, high school graduation, academic achievement) and psychological, emotional or social outcomes (psychosocial well-being, social adjustment, behavioural and emotional disorders, delinquency, substance abuse and diminished quality of interpersonal, family and peer relations). The studies examining some more general outcomes (e.g. civic competency) that cannot be directly related to the well-being of children were, therefore, excluded from the analysis. In addition, 
I had not included those outcomes whose possible interpretations as harmful were grounded in heteronormativity (e.g. the sexual or gender identification of a child) or on value judgements (e.g. the number of sexual partners). Finally, the present review focused on studies that explicitly compared outcomes of children of sameand opposite-sex couples. In the absence of such an explicit comparison, it is impossible to evaluate to what extent a potentially harmful outcome can be attributed to the sexual orientation of the child's parents and to what extent this outcome can be linked to other characteristics of the children or their family structure. In this paper, therefore, I defined as "children from families of same-sex partners" only those children who had grown up in the household of same-sex partners or who had been raised by a same-sex couple for most of their lives. This definition did not include children raised by a single parent of homosexual orientation or children who had not lived in the household of their parent of homosexual orientation. When the studies included in the analysis used a different definition of children of same-sex parents, this was indicated when discussing the operationalisation of categories.

Following the introductory section outlining the development of the field and identifying the debate about the scientific consensus on the well-being of children of lesbians and gays, in the main part of the text I reviewed the existing quantitative studies on random representative samples which compared the outcomes of children from families of same- and opposite-sex partners. This is followed by the discussion on the main points of debate, and then, in the conclusion, I reconsidered the question of the scientific consensus about the outcomes of children of same-sex partners.

\section{Studies on Homoparentality and the Scientific Consensus about the Outcomes of Children from Families of Same- and Opposite-Sex Partners}

The research on homoparentality started in the late 1970s and early 1980s. At first, these studies examined mostly lesbian families in which the majority of the children had been born in previous heterosexual relationships of the mothers (Biblarz and Savci, 2010). The analysed outcomes were primarily related to the division of labour, parental investment and gender roles in the family. Even though some of the studies mentioned children's outcomes related to gender and sexual orientation, emotional and cognitive development and behavioural adjustment, these studies generally did not focus on the outcomes of children of homosexual parents (Biblarz and Savci, 2010; Marks, 2012). In addition, these studies were mostly based on small samples of convenience. This situation reflected the social context characterized by little institutional recognition of same-sex partners. In 
these circumstances, many same-sex couples, and men in particular, found it hard to plan their families. Lesbian and gay families of that time were, therefore, a very vulnerable and hard-to-reach group (Biblarz and Savci, 2010).

At the beginning of the $21^{\text {st }}$ century, institutional changes in many Western countries brought about greater recognition of the rights of LGBT individuals and their families. As a consequence, the research focus shifted to planned parenthood of same-sex couples or persons of homosexual orientation (Biblarz and Savci, 2010). Lesbians and their children still dominated the studies, but gay fathers were included more frequently. Nevertheless, the experiences of bisexual families, especially transgender parents, remained marginal to the research (Biblarz and Savci, 2010). The studies had also became more methodologically advanced. In the Anglo-Saxon (mostly American) context, this period was marked by the emergence of the first studies of families of same-sex partners conducted on large, nationally representative samples. The second decade of the $21^{\text {st }}$ century was in many Western countries marked by the growing debate on the legalisation of same-sex marriage and the right of LGBT individuals to have children. As a result of that debate, children's outcomes - psychosocial and educational outcomes in particular became the focal point of the emerging research. These outcomes were then compared to the outcomes of children from families of opposite-sex couples or parents of heterosexual orientation (American Sociological Association, 2015).

Just as the issue of homoparentality is controversial in today's society, so have studies of homoparentality caused debate in social sciences. That debate is primarily centred on the question of different outcomes for children of same- and opposite-sex partners. The main American professional organisations of psychologists and sociologists suggested that the scientific community had reached the consensus about there being no statistically significant differences between the outcomes of children of same- and opposite-sex parents (American Psychology Association, 2005; American Sociological Association, 2015). This conclusion, however, is imprecise. In one of the first meta-studies of quantitative research, Stacey and Biblarz (2001) warned that some minor differences in outcomes can be detected, primarily related to gender behaviour and identity. Almost a decade later, Biblarz and Stacey (2010) noted that a similar pattern still held. The differences in the outcomes for children of different- and same-sex (mostly lesbian) couples were in a majority of cases not statistically significant. In rare cases when they were significant, this was mostly manifested by higher levels of gender role equality for children of lesbians. As far as other differences in psychosocial and educational outcomes were concerned, they could be attributed to other family characteristics, such as stability of family structure, and not to the parents' sexual orientation 
(American Sociological Association, 2015; Gates, 2015). Therefore, it is more correct to state that the majority of published research supports the argument that there are no differences in harmful outcomes - or benefits - for children of sameor opposite-sex couples that could be attributed to the sexual orientation of their parents (Powell et al., 2016). The conclusion that the scientific consensus on samesex parenting had already been reached was further supported by Adams and Light's analysis (2015) of a network of citations on homoparentality in existing scientific databases. They conducted their analysis on a sample of 19,439 studies published between 1977 and 2013 in the Web of Science database, and they further conducted content analysis of $10 \%$ of the most influential papers on homoparentality, written during various periods.

Nevertheless, a smaller group of authors (e.g. Marks, 2012; Allen, 2015) still claims that it is too early to speak of a scientific consensus about there being no differences in (harmful) outcomes of children of same- and opposite-sex partners. These authors base their objections on methodological weaknesses and problematic samples of the majority of existing studies. First, they pointed out limited generalization of results based on many qualitative studies conducted on small samples of convenience, which mostly included only lesbian families, and those often more educated, more affluent and white. Second, they objected to thenexisting quantitative studies for using relatively small samples, which resulted in weaker statistical power of their analyses, i.e. the probability that the differences which were present in the population were not detected in the sample as being statistically significant. Marks (2012) and Allen (2015) claimed that forming a final opinion on same-sex parenting required solely the results of quantitative studies conducted on large random samples. They also highlighted the desirability of longitudinal studies on random samples, which were yet to be carried out. In their opinion, as long as there was even a single study that found poorer outcomes for children of same-sex partners (such as studies by Regnerus /2012a/, Allen /2013/, Allen, Pakaluk and Price /2013/, and Sullins /2015a, 2015b/), one cannot claim scientific consensus on homoparentality.

Is postponing such evaluations about same-sex parenting research truly justified or should we accept the claim about the existing consensus in the scientific community? First, so easily dismissing the results of numerous qualitative studies, as Marks (2012) and Allen (2015) did, is not an acceptable argument within the framework of social sciences. Qualitative studies are a legitimate and valuable tool, necessary for understanding any social phenomenon. Although limited probabilistic generalisation of results from small studies on convenience samples is undoubtedly their weakness, these types of studies accomplish other scientific goals. Among 
other things, as emphasised by Gobo (2008) in a discussion on theoretical generalisation, qualitative studies can identify a deeper structure of social phenomena or explain the mechanisms of their emergence or change. Furthermore, an implicit assumption that quantitative studies are superior solely because they include large numbers or are based on probabilistic sampling, neglect the fact that such studies can be methodologically problematic or that conclusions based on probabilistic samples can be unjustified and invalid. Indeed, these types of problems were highlighted by the present review. Therefore, it is deeply flawed to claim that scientific consensus cannot be based on results of smaller qualitative studies on homoparentality conducted on convenience samples, especially if one takes into account that the results of such studies have been consistent for decades (American Sociological Association, 2015).

Second, although Marks (2012) and Allen (2015) were undoubtedly right when they emphasised the limitations of statistical analyses and conclusions of quantitative studies conducted on small samples of convenience, such studies also contributed to the understanding of homoparentality, particularly when they examined small and hard-to-reach populations (Powell et al., 2016). In addition, such studies also included longitudinal studies of families of lesbians that allowed for long-term monitoring of outcomes of children growing up in these families. This data is undoubtedly relevant, even when based on non-random samples. ${ }^{2}$

Nevertheless, considering that the main strength of quantitative research is indeed the possibility of probabilistic generalisation, it makes sense to limit the discussion about the validity of the results to the studies that are methodologically most advanced in that regard. Currently, these are the studies based on large random representative samples that explicitly compare harmful outcomes of children of same- and opposite-sex couples. Therefore, in the main part of this paper, I have focused on such studies and on the conclusions that can or cannot be inferred from the data and the type of analysis they used. If quantitative studies on random samples that follow the principle of good scientific practice or are most advanced methodologically do not support the consensus on the outcomes of children of same-sex parents, then this review must conclude that is indeed premature to talk about the scientific consensus on homoparentality. On the other hand, if the methodological weaknesses and limitations to the conclusions primarily

\footnotetext{
${ }^{2}$ See, for example, the British Longitudinal Study of Lesbian Families (Tasker and Golombok, 1997), the British Study of Children Raised in Fatherless Families from Infancy (Golombok and Badger, 2010), the Belgian Study of Lesbian Parenthood (Vanfraussen, Ponjaert-Kristoffersen and Brewaeys, 2003), the American National Longitudinal Lesbian Family Study (https:// www.nllfs.org/publications) or the Dutch Lesbian Longitudinal Family Study (Van Rijn-van Gelderen, Bos and Gartrell, 2015).
} 
characterise the studies which detected differences in harmful outcomes, but not those that found no significant differences, then the conclusion must be in favour of the existing consensus.

\section{Quantitative Studies on Random Representative Samples that Compare Outcomes of Children from Families of Same- and Opposite-Sex Partners}

Quantitative studies on random representative samples that include children of same-sex couples are a relatively recent development, mostly limited to the AngloSaxon context. One of the pioneers in the field, Susan Golombok, conducted the first studies of lesbian families using a combination of random and snowball sampling (Golombok et al., 2003). However, in this review I included only those studies comparing outcomes of children from families of same- and opposite-sex couples that were conducted fully on random representative samples. The first such studies were released in the early $21^{\text {st }}$ century. By doing a keyword search of concepts related to homoparentality and children's outcomes in the search engine Google Scholar, and also additionally examining the methodological characteristics of all studies referenced in the existing review articles, I have identified all the existing studies which meet the criteria specified in the introductory section, and which had been published in peer-reviewed journals. ${ }^{3}$ This includes 15 studies in total, published from 2004 to February 2017. Some of the publications were based on the same data, but analysed different outcomes, while others used the same data and the same outcomes, but conducted the analysis by using other statistical models and/or different samples of children of same- and opposite-sex partners.

Based on the discussions in the existing review articles, I have identified three key points of debate which I then spotlighted in my analysis. These are (1) the sample characteristics, (2) the operationalisation of the category of children of same-sex partners, and (3) omitting an important control variable (family stability). The last point is also related to the question of whether equivalent forms of families of same- and opposite-sex partners were compared. Table 1 shows the summary of these data for all analysed studies. The discussion of the sample characteristics addressed two questions. The first question examined the main sample on which the study was based. For a study to be included in the present review, it had to be based on a large random sample representative for a particular population (e.g. all

\footnotetext{
${ }^{3}$ Google Scholar gives a wider, and often a more recent overview of publications than the closed, i.e. moderated databases such as Scopus or Web of Science. It is, therefore, more efficient for the purpose of initial identification of relevant works. I used the following keywords in the search: homoparentality, same-sex / LGBT / lesbian / gay parents /parenting / family, children, outcomes / well-being. I also took advantege of the Google Scholar function to find similar articles or articles citing the identified publications.
} 
households or all children of a certain age). The second question examined the size of an analysed sample. As the numbers of children of same-sex partners in the population were relatively small, it was not possible to randomly select such children from the main sample. Instead, the analyses included all such children identified in the main sample based on particular criteria. The size of the sample directly depended on the criterion used to identify children of same-sex partners, and, in turn, it determined the statistical power of the analysis.

The studies which included a relatively small total number of children in their analyses (under 100) I labelled "the studies of the first wave". Generally, these were the first studies of homoparentality ever conducted on large random samples. The studies which included more than 100 children from different family structures I labelled "the studies of the second wave". The studies that were most often identified as problematic were those based on samples of less than 500 children (see in Allen, 2013, 2015). Some authors also pointed out as problematic the data that was not collected directly from the children but from the parents (Marks, 2012). However, this being a common practice in the research on children, I did not discuss it specifically, although I provided the information on the source of data in Table 1.

Operationalisation of the category of children of same-sex partners refers to the criteria that were used to identify the children in the main sample and select them for the analysis. This is a crucial piece of information for any evaluation of the validity of conclusions about the outcomes of children from families of samesex couples. The most frequent criticisms of the category of children of same-sex partners most often included limiting the sample exclusively to children of lesbian couples (Marks, 2012; Allen, 2015), a static definition of those children (including all children who at some point lived in the household of a same-sex couple, regardless of whether they really grew up in said household; Rosenfeld, 2013), and a too wide definition of that category (Cheng and Powell, 2015).

Finally, the third point of debate brought into question the statistical models of studies that compared outcomes of children from families of same- and oppositesex partners, but which did not include an appropriate measure of family stability. Since this is a variable consistently found in family studies as an important determinant of the children's outcomes (Amato, 2012, 2015; Perrin, Cohen and Caren, 2013), omitting this variable can result in unreliable results and invalid interpretations. Omitting family stability becomes particularly problematic if the compared family structures were not equivalent in regard to their stability. 


\section{Table 1: Main Characteristics and the Results of Studies about Outcomes of Children from Families of Same-Sex Partners Based on Random Representative Samples, Published 2014- 2017.}

\begin{tabular}{|c|c|c|c|c|c|c|}
\hline \multirow[t]{2}{*}{ study* } & \multicolumn{2}{|c|}{ characteristics of sample } & \multirow{2}{*}{$\begin{array}{l}\text { operationalisation } \\
\text { definition of children of } \\
\text { same-sex partners }\end{array}$} & \multicolumn{2}{|c|}{ analysis } & \multirow[b]{2}{*}{$\begin{array}{l}\text { results } \\
\text { findings of } \\
\text { statistically } \\
\text { significant } \\
\text { difference in } \\
\text { harmful } \\
\text { children's } \\
\text { outcome }\end{array}$} \\
\hline & respondents & $\begin{array}{l}\text { total } \\
\text { number of } \\
\text { children in } \\
\text { sample } \\
\text { (number of } \\
\text { children } \\
\text { defined as } \\
\text { children of } \\
\text { same-sex } \\
\text { partners) }\end{array}$ & & $\begin{array}{l}\text { comparison of } \\
\text { families of same- } \\
\text { and opposite-sex } \\
\text { partners }\end{array}$ & $\begin{array}{l}\text { inclusion } \\
\text { of family } \\
\text { stability } \\
\text { factor }\end{array}$ & \\
\hline $\begin{array}{l}\text { Wainright, } \\
\text { Russell } \\
\text { and } \\
\text { Patterson } \\
(2004)\end{array}$ & $\begin{array}{l}\text { adolescents } \\
\text { and } \\
\text { parents/legal } \\
\text { guardians }\end{array}$ & $88(44)$ & $\begin{array}{l}\text { limited (lesbian } \\
\text { families), static (issue of } \\
\text { growing up) - children } \\
\text { (12-18) who lived in a } \\
\text { household with a lesbian } \\
\text { couple in } 1994\end{array}$ & $\begin{array}{l}\text { matching samples } \\
\text { - analysed families } \\
\text { shared the same } \\
\text { characteristics }\end{array}$ & no & $\begin{array}{c}\text { no } \\
\text { (psychosocial } \\
\text { adjustment, } \\
\text { school } \\
\text { outcomes, } \\
\text { romantic } \\
\text { relationships) }\end{array}$ \\
\hline $\begin{array}{l}\text { Wainright } \\
\text { and } \\
\text { Patterson } \\
\text { (2006) }\end{array}$ & $\begin{array}{l}\text { adolescents } \\
\text { and } \\
\text { parents/legal } \\
\text { guardians }\end{array}$ & $88(44)$ & $\begin{array}{l}\text { limited (lesbian } \\
\text { families), static (issue of } \\
\text { growing up) - children } \\
\text { (12-18) who lived in a } \\
\text { household with a lesbian } \\
\text { couple in } 1994\end{array}$ & $\begin{array}{l}\text { matching samples } \\
\text { - analysed families } \\
\text { shared the same } \\
\text { characteristics }\end{array}$ & no & $\begin{array}{c}n o \\
\text { (delinquency, } \\
\text { victimisation, } \\
\text { substance use) }\end{array}$ \\
\hline $\begin{array}{l}\text { Wainright } \\
\text { and } \\
\text { Patterson } \\
\text { (2008) }\end{array}$ & $\begin{array}{l}\text { adolescents } \\
\text { and } \\
\text { parents/legal } \\
\text { guardian }\end{array}$ & $88(44)$ & $\begin{array}{l}\text { limited (lesbian } \\
\text { families), static (issue of } \\
\text { growing up) - children } \\
\text { (12-18) who lived in a } \\
\text { household with a lesbian } \\
\text { couple in } 1994\end{array}$ & $\begin{array}{l}\text { matching samples } \\
\text { - analysed families } \\
\text { shared the same } \\
\text { characteristics }\end{array}$ & no & $\begin{array}{c}\text { no } \\
\text { (quality of } \\
\text { family and } \\
\text { peer relations) }\end{array}$ \\
\hline $\begin{array}{l}\text { Fedewa } \\
\text { and Clark } \\
(2009)\end{array}$ & $\begin{array}{l}\text { children and } \\
\text { parents/legal } \\
\text { guardians }\end{array}$ & $70(35)$ & $\begin{array}{l}\text { static (issue of growing } \\
\text { up) - first-grade children } \\
\text { who lived in a household } \\
\text { with a same-sex couple } \\
\text { in } 2000\end{array}$ & $\begin{array}{l}\text { one vs one } \\
\text { category - } \\
\text { children from } \\
\text { same-sex families } \\
\text { were compared to } \\
\text { the same number } \\
\text { of children from } \\
\text { opposite-sex } \\
\text { partners' families }\end{array}$ & no & $\begin{array}{c}\text { no } \\
\text { (academic } \\
\text { achievement } \\
\text { in reading and } \\
\text { mathematics, } \\
\text { social } \\
\text { adjustment) }\end{array}$ \\
\hline $\begin{array}{l}\text { Rosenfeld } \\
(2010)\end{array}$ & $\begin{array}{l}\text { parents/legal } \\
\text { guardians }\end{array}$ & $\begin{array}{l}716,740 \\
(3,502)\end{array}$ & $\begin{array}{l}\text { satisfactory - primary } \\
\text { school children who } \\
\text { lived in the household of } \\
\text { a same-sex couple } \\
\text { (including one biological } \\
\text { parent) for at least five } \\
\text { years }\end{array}$ & $\begin{array}{l}\text { one vs more } \\
\text { categories - } \\
\text { children of same- } \\
\text { sex couples were } \\
\text { compared to } \\
\text { children from } \\
\text { different family } \\
\text { structures }\end{array}$ & $\begin{array}{l}\text { limited- } \\
\text { residential } \\
\text { stability } \\
\text { (living in } \\
\text { the same } \\
\text { household) } \\
\text { for at least } \\
\text { five years }\end{array}$ & $\begin{array}{c}\text { no } \\
\text { (grade } \\
\text { retention) }\end{array}$ \\
\hline $\begin{array}{l}\text { Allen, } \\
\text { Pakaluk } \\
\text { and Price } \\
\text { (2013) } \\
\text { (alternative } \\
\text { analysis of } \\
\text { Rosenfeld, } \\
2010)\end{array}$ & $\begin{array}{l}\text { parents/legal } \\
\text { guardians }\end{array}$ & $\begin{array}{c}1,610,880 \\
(8,632)\end{array}$ & $\begin{array}{l}\text { static (issue of growing } \\
\text { up) - primary school } \\
\text { children who lived in the } \\
\text { household of a same-sex } \\
\text { couple (no biological } \\
\text { relation to the child } \\
\text { needed) in } 2000\end{array}$ & $\begin{array}{l}\text { one vs more } \\
\text { categories - } \\
\text { children of same- } \\
\text { sex couples were } \\
\text { compared to } \\
\text { children from } \\
\text { different family } \\
\text { structures }\end{array}$ & no & $\begin{array}{c}\text { yes } \\
\text { (grade } \\
\text { retention) }\end{array}$ \\
\hline
\end{tabular}




\begin{tabular}{|c|c|c|c|c|c|c|}
\hline \multirow[t]{2}{*}{ study* } & \multicolumn{2}{|c|}{ characteristics of sample } & \multirow{2}{*}{\begin{tabular}{l}
\multicolumn{1}{c}{ operationalisation } \\
definition of children of \\
same-sex partners
\end{tabular}} & \multicolumn{2}{|c|}{ analysis } & \multirow[b]{2}{*}{$\begin{array}{l}\text { results } \\
\text { findings of } \\
\text { statistically } \\
\text { significant } \\
\text { difference in } \\
\text { harmful } \\
\text { children's } \\
\text { outcome }\end{array}$} \\
\hline & respondents & $\begin{array}{l}\text { total } \\
\text { number of } \\
\text { children in } \\
\text { sample } \\
\text { (number of } \\
\text { children } \\
\text { defined as } \\
\text { children of } \\
\text { same-sex } \\
\text { partners) }\end{array}$ & & $\begin{array}{l}\text { comparison of } \\
\text { families of same- } \\
\text { and opposite-sex } \\
\text { partners }\end{array}$ & $\begin{array}{l}\text { inclusion } \\
\text { of family } \\
\text { stability } \\
\text { factor }\end{array}$ & \\
\hline $\begin{array}{l}\text { Potter } \\
\text { (2012) } \\
\text { (longitudi } \\
\text { nal study) }\end{array}$ & $\begin{array}{l}\text { children and } \\
\text { parents/legal } \\
\text { guardians }\end{array}$ & $\begin{array}{c}19,043 \\
(158)\end{array}$ & $\begin{array}{l}\text { static (issue of growing } \\
\text { up) - children followed } \\
\text { since kindergarten to the } \\
\text { eighth grade, who lived } \\
\text { in a household with a } \\
\text { same-sex couple during } \\
\text { at least one wave of data } \\
\text { collection }\end{array}$ & $\begin{array}{l}\text { one vs more } \\
\text { categories - } \\
\text { children of same- } \\
\text { sex couples were } \\
\text { compared to } \\
\text { children from } \\
\text { different family } \\
\text { structures }\end{array}$ & $\begin{array}{l}\text { yes- } \\
\text { changes in } \\
\text { family } \\
\text { structure } \\
\text { through } \\
\text { time } \\
\text { included } \\
\text { in the } \\
\text { analysis } \\
\text { as "family } \\
\text { transitions" }\end{array}$ & $\begin{array}{c}n o \\
\text { (academic } \\
\text { achievement } \\
\text { in } \\
\text { mathematics) }\end{array}$ \\
\hline $\begin{array}{l}\text { Potter and } \\
\text { Potter } \\
\text { (2016) } \\
\text { (longitudi- } \\
\text { nal study) }\end{array}$ & $\begin{array}{l}\text { children, } \\
\text { parents/legal } \\
\text { guardians, } \\
\text { teachers }\end{array}$ & $\begin{array}{c}19,130 \\
(155)\end{array}$ & $\begin{array}{l}\text { static (issue of growing } \\
\text { up) - children followed } \\
\text { since kindergarten to the } \\
\text { fifth grade, who lived in } \\
\text { a household with a same- } \\
\text { sex couple during at least } \\
\text { one wave of data } \\
\text { collection }\end{array}$ & $\begin{array}{l}\text { one vs more } \\
\text { categories - } \\
\text { children of same- } \\
\text { sex couples were } \\
\text { compared to } \\
\text { children from } \\
\text { different family } \\
\text { structures }\end{array}$ & $\begin{array}{c}\text { yes - } \\
\text { changes in } \\
\text { family } \\
\text { structure } \\
\text { through } \\
\text { time } \\
\text { included } \\
\text { in the } \\
\text { analysis } \\
\text { as "family } \\
\text { transitions" }\end{array}$ & $\begin{array}{c}\text { no } \\
\text { (psychosocial } \\
\text { well-being) }\end{array}$ \\
\hline $\begin{array}{l}\text { Regnerus } \\
(2012 a)\end{array}$ & young adults & $2,988(236)$ & $\begin{array}{l}\text { too wide (includes } \\
\text { respondents who never } \\
\text { lived with a same-sex } \\
\text { couple) - young adults } \\
(18-39) \text { whose parents } \\
\text { had at least one same-sex } \\
\text { relationship during the } \\
\text { respondent's childhood }\end{array}$ & $\begin{array}{l}\text { one vs more } \\
\text { categories - } \\
\text { children of parents } \\
\text { with at least one } \\
\text { same-sex } \\
\text { relationship were } \\
\text { compared to } \\
\text { children from } \\
\text { different family } \\
\text { structures }\end{array}$ & no & $\begin{array}{c}\text { yes } \\
\text { (emotional, } \\
\text { social and } \\
\text { relational } \\
\text { outcomes) }\end{array}$ \\
\hline $\begin{array}{l}\text { Cheng and } \\
\text { Powell } \\
(2015) \\
\text { (alternative } \\
\text { analysis of } \\
\text { Regnerus, } \\
\text { 2012a) }\end{array}$ & young adults & $\begin{array}{c}\approx \\
3,000^{* *}(51)\end{array}$ & $\begin{array}{l}\text { static (issue of growing } \\
\text { up) - young adults (18- } \\
39 \text { ) who lived in a } \\
\text { household with a same- } \\
\text { sex couple for at least a } \\
\text { year during their } \\
\text { childhood }\end{array}$ & $\begin{array}{l}\text { one vs more } \\
\text { categories - } \\
\text { children of same- } \\
\text { sex couples were } \\
\text { compared to } \\
\text { children from } \\
\text { different family } \\
\text { structures }\end{array}$ & no & $\begin{array}{c}\text { no } \\
\text { (emotional, } \\
\text { social and } \\
\text { relational } \\
\text { outcomes) }\end{array}$ \\
\hline $\begin{array}{l}\text { Allen } \\
(2013)\end{array}$ & $\begin{array}{l}\text { youth (17-22) } \\
\text { and parents }\end{array}$ & $>500 * *$ & $\begin{array}{l}\text { static (issue of growing } \\
\text { up) - youth (17-22) who } \\
\text { identify themselves as } \\
\text { children of a married or } \\
\text { cohabiting same-sex } \\
\text { couple and lived in their } \\
\text { household in } 2006\end{array}$ & $\begin{array}{l}\text { one vs more } \\
\text { categories - } \\
\text { children of same- } \\
\text { sex couples were } \\
\text { compared to } \\
\text { children from } \\
\text { different family } \\
\text { structures }\end{array}$ & $\begin{array}{l}\text { limited-(1) } \\
\text { household } \\
\text { move in } \\
\text { the past } \\
\text { year; (2) } \\
\text { household } \\
\text { move in } \\
\text { the past } \\
\text { five years } \\
\text { (additional } \\
\text { analyses) }\end{array}$ & $\begin{array}{l}y e s / n o \text { (in } \\
\text { additional } \\
\text { analyses) } \\
\text { (high school } \\
\text { graduation) }\end{array}$ \\
\hline
\end{tabular}




\begin{tabular}{|c|c|c|c|c|c|c|}
\hline \multirow[t]{2}{*}{ study* } & \multicolumn{2}{|c|}{ characteristics of sample } & \multirow{2}{*}{\begin{tabular}{l}
\multicolumn{1}{c}{ operationalisation } \\
definition of children of \\
same-sex partners
\end{tabular}} & \multicolumn{2}{|c|}{ analysis } & \multirow[b]{2}{*}{$\begin{array}{l}\text { results } \\
\text { findings of } \\
\text { statistically } \\
\text { significant } \\
\text { difference in } \\
\text { harmful } \\
\text { children's } \\
\text { outcome }\end{array}$} \\
\hline & respondents & $\begin{array}{l}\text { total } \\
\text { number of } \\
\text { children in } \\
\text { sample } \\
\text { (number of } \\
\text { children } \\
\text { defined as } \\
\text { children of } \\
\text { same-sex } \\
\text { partners) }\end{array}$ & & $\begin{array}{l}\text { comparison of } \\
\text { families of same- } \\
\text { and opposite-sex } \\
\text { partners }\end{array}$ & $\begin{array}{l}\text { inclusion } \\
\text { of family } \\
\text { stability } \\
\text { factor }\end{array}$ & \\
\hline $\begin{array}{l}\text { Sullins } \\
\text { (2015a) }\end{array}$ & parents & $\begin{array}{c}195,240^{* * *} \\
(512)\end{array}$ & $\begin{array}{l}\text { static (issue of growing } \\
\text { up) - children (4-17) } \\
\text { who lived in a household } \\
\text { with a married or } \\
\text { cohabiting same-sex } \\
\text { couple during an } \\
\text { unidentified period }\end{array}$ & $\begin{array}{l}\text { one vs. one } \\
\text { category- } \\
\text { children of same- } \\
\text { sex couples were } \\
\text { compared to } \\
\text { children of } \\
\text { opposite-sex } \\
\text { couples }\end{array}$ & no & $\begin{array}{c}\text { yes } \\
\text { (Attention- } \\
\text { Deficit } \\
\text { Hyperactivity } \\
\text { Disorder) }\end{array}$ \\
\hline $\begin{array}{l}\text { Sullins } \\
(2015 b)\end{array}$ & parents & $\begin{array}{c}207,007^{* * *} \\
\quad(512)\end{array}$ & $\begin{array}{l}\text { static (issue of growing } \\
\text { up) - children (4-17) } \\
\text { who lived in a household } \\
\text { with a married or } \\
\text { cohabiting same-sex } \\
\text { couple during an } \\
\text { unidentified period }\end{array}$ & $\begin{array}{l}\text { one vs one/more } \\
\text { categories - } \\
\text { children of same- } \\
\text { sex couples were } \\
\text { compared to (1) } \\
\text { children of } \\
\text { opposite-sex } \\
\text { couples and (2) } \\
\text { children from } \\
\text { different family } \\
\text { structures }\end{array}$ & $\begin{array}{l}\text { problematic } \\
\text { - home } \\
\text { ownership } \\
\text { as a } \\
\text { measure } \\
\text { of family } \\
\text { stability }\end{array}$ & $\begin{array}{c}\text { yes } \\
\text { (serious } \\
\text { emotional } \\
\text { difficulties, } \\
\text { problems with } \\
\text { concentration } \\
\text { and/or getting } \\
\text { along with } \\
\text { other people) }\end{array}$ \\
\hline $\begin{array}{l}\text { Bos et al. } \\
\text { (2016) }\end{array}$ & parents & $190(95)$ & $\begin{array}{l}\text { limited (lesbian families) } \\
\text { - children (6-17) who } \\
\text { had been growing up } \\
\text { with a lesbian couple } \\
\text { since birth }\end{array}$ & $\begin{array}{l}\text { matching samples } \\
\text { - analysed families } \\
\text { share the same } \\
\text { main } \\
\text { characteristics }\end{array}$ & $\begin{array}{l}\text { yes - only } \\
\text { stable } \\
\text { families in } \\
\text { which } \\
\text { parents } \\
\text { were } \\
\text { continually } \\
\text { together } \\
\text { since the } \\
\text { child's } \\
\text { birth }\end{array}$ & $\begin{array}{c}\text { no } \\
\text { (health, } \\
\text { emotional } \\
\text { difficulties, } \\
\text { coping } \\
\text { behaviour, } \\
\text { learning } \\
\text { behaviour) }\end{array}$ \\
\hline $\begin{array}{l}\text { Bos, } \\
\text { Kuyper } \\
\text { and } \\
\text { Gartrell } \\
(2017)\end{array}$ & parents & $190(95)$ & $\begin{array}{l}\text { satisfactory - children } \\
(5-18) \text { who lived in an } \\
\text { intact family of a same- } \\
\text { sex couple for at least } \\
\text { the last two years } \\
\text { (children were not } \\
\text { adopted, step- or foster } \\
\text { children) }\end{array}$ & $\begin{array}{l}\text { matching samples } \\
\text { - analysed families } \\
\text { share the same } \\
\text { main } \\
\text { characteristics }\end{array}$ & $\begin{array}{l}\text { yes - only } \\
\text { stable } \\
\text { families in } \\
\text { which the } \\
\text { parents } \\
\text { did not } \\
\text { divorce } \\
\text { /separate } \\
\text { in } \\
\text { previous } \\
\text { two years }\end{array}$ & $\begin{array}{c}\text { no } \\
\text { (emotional } \\
\text { and } \\
\text { behavioural } \\
\text { difficulties, } \\
\text { hyperactivity, } \\
\text { peer } \\
\text { problems) }\end{array}$ \\
\hline
\end{tabular}

* Studies conducted on the same respondents are grouped together and marked with the same background colour.

** The published article does not contain accurate information about the size of the (sub)sample.

*** The two Sullins' articles using analyses conducted on the same data contain contradictory information about the size of the main sample. 


\subsection{The First Wave of Quantitative Research on Homoparentality}

The first wave of research on homoparentality on random representative samples included US studies published from 2004 to 2009 by Wainright and colleagues (Wainright and Patterson, 2006, 2008; Wainright, Russell and Patterson, 2004), and Fedewa and Clark (2009) (Table 1). These are the first studies completely based on large random nationally representative samples. Wainright and colleagues used the National Longitudinal Study of Adolescent Health, while Fedewa and Clark used the Early Childhood Longitudinal Study. ${ }^{4}$ Nevertheless, both studies included less than 100 children total in the analyses. The sample sizes in both cases were determined by the number of children of same-sex partners. Operationalized as the children who, at the moment of data collection, lived in a household with a samesex couple, each study included less than 50 children of same-sex partners. The number of children of same-sex partners was matched with an equal number of children who lived in a household with an opposite-sex couple. Wainright and colleagues selected those families of opposite-sex couples that shared the same characteristics as the families of same-sex couples, whereas Fedewa and Clark randomly sampled the families of opposite-sex couples. Moreover, Wainright and colleagues excluded families of gay fathers from the analysis due to the small number of such families in the main sample, whereas Fedewa and Clark's study included them as well, though in a smaller number.

The studies of the first wave compared educational and psychosocial outcomes (Table 1) of children of same- and opposite-sex couples and found no statistically significant differences between the two. Therefore, the results of the first quantitative studies on large random samples were consistent with the results of previous quantitative and qualitative studies conducted on convenience samples. Nevertheless, this research has attracted two main objections regarding the validity of its results. First, since the comparison of the outcomes was based on small samples, it cannot be conclusively claimed that the finding of no statistical difference in the sample would uphold for the population (Marks, 2012; Allen, 2013, 2015). Second, Wainright and colleagues' analyses included solely children from lesbian families, which is problematic for the generalisation of results; the patterns of lesbian families may not hold for gay families (Marks, 2012; Allen, 2013, 2015).

In addition, the operationalisation of the category of children of same-sex partners used by these studies of the first wave was static. It is unknown, in fact,

\footnotetext{
${ }^{4}$ In both cases, the data were treated as cross-sectional data - only one wave of research was analysed.
} 
how long the children had lived in a household with a same-sex couple - it is only known that they lived in that household at the year of data collection. Therefore, it is hard to estimate to what extent the outcomes for those children can be attributed to them being raised or growing up in the family of a same-sex couple (see Rosenfeld, 2013, for a similar criticism of Allen, Pakaluk and Price, 2013). In addition, even though at the moment this research was published, the debate about the inclusion of family stability control had not yet developed - and omitting this variable in these cases did not influence the finding of no differences in harmful outcomes - that control was precisely one of the important variables the authors did not include in their analyses.

However, the main strength of these studies was their ability to compare equivalent forms of family structures. With Wainright and colleagues, for example, the parents' sexual orientation, assumed from living in a household with a partner of the same or different $\operatorname{sex}^{5}$, is a characteristics that varies, while other family characteristics are identical. Therefore, these types of analyses undoubtedly contributed to a systematic comparison of outcomes of children of same- and opposite-sex couples, and should definitely be considered in thinking about these issues. However, it is also obvious that these first studies of this kind had many flaws which will be more or less addressed in later studies. To these studies I turn in the next section.

\subsection{The Second Wave of Quantitative Research on Homoparentality}

The turning point for quantitative research on homoparentality is marked by Rosenfeld's 2010 study which, for the first time ever, used a large nationally representative sample that explicitly controlled for family stability. This study (Rosenfeld, 2010) analysed children's educational outcomes on a sample of 761,279 children randomly selected from the 2000 US Census data (US Census Microdata). The subsample of children of same-sex partners included 3,502 children (2,030 children of lesbian and 1,472 children of gay couples). Further, the category of children of same-sex partners specified that the children had to have lived in a household with a same-sex couple for at least five years. Rosenfeld used this condition as a measure of residential stability, which was, in turn, an indicator of family stability which he held constant in his analyses. Neither the children of

\footnotetext{
${ }^{5}$ These studies, similar to most quantitative studies that followed later, did not contain explicit information about the sexual orientation of the parents. Instead, the researchers used other information to identify homosexual parents. It is unknown whether whether all respondends defined as such indeed identified themselves as gay or lesbian. The only available information is whether a parent lived with a partner of the opposite sex.
} 
same-sex couples nor the children of other family structures had in the previous five years experienced a transition into a different form of family. In his analyses, Rosenfeld compared the outcomes of children of cohabiting same-sex couples against the outcomes of children of married and cohabiting opposite-sex partners. In this manner, he wanted to ensure that the compared family forms were equivalent. Further, he restricted the samples of the main analyses to the children biologically related to the interviewed parent. This strategy was intended to ensure that only stable families were included in the analysis. This led to an exclusion of children born in previous relationships (other families) of both same- and oppositesex couples, as the latter would be indicative of family instability in the past. Despite these precautions, Rosenfeld himself admitted that one of the limitations of his study concerned his inability to use better controls for long-term family stability based on the available data.

Rosenfeld's results suggested that, when controlling for sociodemographic characteristics and the factors associated with academic achievement, such as the parents' educational attainment, there remained no statistically significant differences in the educational outcomes of children of same- and opposite-sex couples. Although this is a methodologically sound study, it encountered criticism from Allen, Pakaluk and Price (2013). These authors conducted an alternative analysis of the same data and came up with different results. This discrepancy stemmed from some key methodological differences between the original study and the alternative analysis. First, Allen and colleagues dropped the condition of at least five years of living in the same household. Instead, they defined all children who at the moment of data collection lived in a household with a same-sex couple as children of same-sex partners, regardless of how long they had lived in such a household. Such a wider definition resulted in a greater sample size - more than $1,610,880$ children were analysed, out of which 8,632 were defined as children of same-sex partners. However, this was also a static definition of the category of children of same-sex partners which did not account for whether these children were indeed raised by a same-sex couple for a longer period of time. Rosenfeld (2013) pointed out Allen and colleagues' inability to know whether the educational outcomes of the children they included in the analysis were determined by the children's earlier experiences in other family structures. This is a considerable limitation to the validity of Allen and colleagues' findings, as many children living in families of same-sex couples were born in broken-up families of opposite-sex partners or were adopted by same-sex couples. Therefore, these children have possibly experienced very different circumstances before entering a family of same-sex parents (Rosenfeld, 2013). 
Despite this limitation, Allen, Pakaluk and Price did not include a control measure for family stability. The closest they get to doing that is by including a variable which measures whether the household moved. However, it is unclear from the article when the household move occurred. Based on the information they provided, this seems to be a measure of whether the household in question ever moved. It is hard to see how such an unspecific measure can control for family stability.

The larger sample size of Allen, Pakaluk and Price's analyses increased the power of statistical tests and made the generalisation based on them more precise. However, the interpretation of the results of their alternative analysis remained questionable. Specifically, Allen, Pakaluk and Price claimed that their results indicated differences in educational outcomes of children from families of sameand opposite-sex couples. However, as Rosenfeld (2013) emphasised, the decision to operationalise the category of children of same-sex couples so widely makes their claim that they measured the outcomes of children raised in households of same-sex partners questionable, since such children had not been clearly identified in the sample.

Studies following Rosenfeld's study were methodologically more sophisticated than those of the first wave. Nevertheless, few managed to reach the level of quality of Rosenfeld's study. Some of these later studies on educational and psychosocial outcomes conducted on large random samples claimed they found significant differences in children's harmful outcomes (Regnerus, 2012a; Allen, 2013; Sullins, 2015a, 2015b) (Table 1). Among those studies, Regnerus' research published in $2012^{6}$ encountered most public attention, but was also met with very strong criticism from the scientific community (e.g. Barrett, 2012; Gates et al., 2012; Perrin, Cohen and Caren, 2013; American Sociological Association, 2015).

Regnerus' study (2012a) was based on a large US random and nationally representative sample of 2,988 young adults whose data were collected for the purpose of the New Family Structures Study. The advantages of these data are numerous. Regnerus had access to very detailed information about his research participants and was able to analyse the differences in 40 outcomes from social, emotional and relational domains. These outcomes, however, also included some that cannot unquestionably be considered harmful, such as sexual orientation or the number of sexual partners. The sample of young adult respondents categorised as children of same-sex parents consisted of 236 individuals. That is a larger sample than the majority of those used in the first wave of research, but still relatively

\footnotetext{
${ }^{6}$ This study is in Croatia know as the Texan Study.
} 
small. Therefore, this study also suffers from problem of a small sample size that persistently characterizes studies on homoparentality (Eggebeen, 2012; Osborne, 2012). However, another methodological weakness of Regnerus' study is a much greater problem; Regnerus used a very problematic operationalisation of children of same-sex parents (Perrin, Cohen and Caren, 2013; American Sociological Association, 2015). All respondents with a parent who, to the respondents' knowledge, had a same-sex relationship during their childhood were categorised as children of same-sex parents, regardless whether or not the respondents ever lived with that parent or their same-sex partner. Therefore, not only did the sample contain (then-adult) children who had not grown up with a same-sex couple, but it also contained children who had spent most of their childhood in another family structure. Most likely, children who had never lived in a family of same-sex partners were included as well. The same problem remained in the additional analyses by which Regnerus' (2012b) responded to criticism of his work.

Furthermore, some critics pointed out that Regnerus compared families not equivalent in terms of family stability. For instance, in a letter to the editor of the Social Science Research journals, co-signed by more than a hundred academics, Gates emphasised how Regnerus defined also as individuals with a "lesbian mother" or a "gay father" those respondents whose parents, later in their life, divorced their opposite-sex partner, who remarried an opposite-sex partner, and those who were raised by a single parent, if such respondents stated they were aware of at least one same-sex relationship of one of their parents (Gates et al., 2012). That means that Regnerus in the interpretation of his results could not differentiate the effect of having a parent with a continual same-sex relationship from the effect of experiencing different family structures and transitions, such as the experience of a divorce, parents' remarrying or living with a single parent (Osborne, 2012; Gates et al., 2012). Furthermore, Regnerus compared children of same-sex parents (who were, in fact, children who grew up in family structures of different stability) with children of intact families of two married heterosexual parents, the latter known to be the most stable type of heterosexual family (American Sociological Association, 2015). He further artificially made the category of "intact biological family" even more stable by excluding respondents who had spent their entire childhood in an intact biological family, but whose parents separated or divorced in their adulthood (Cheng and Powell, 2015). Despite all this, in any of his analyses, Regnerus did not use not a single measure of family stability, and was therefore unable to estimate its effects. Therefore, Regnerus' claim that his results suggested poorer outcomes of children from families of samesex parents is questionable, to say the least. When those same data were analysed in 
a more methodologically appropriate way, like Cheng and Powell (2015) did, the results showed that the outcomes of children who lived with a same-sex couple were comparable to the outcomes of children from other family structures, including intact biological families.

The main difference between the original Regnerus' study and Cheng and Powell's alternative analysis is that Cheng and Powell defined as children of samesex couples only those respondents who had lived with a same-sex couple for at least a year of their childhood. Furthermore, in the category of children of intact biological families they included all those respondents who had lived in such a family their whole childhood, even if their parents did not necessarily stay married after the children reached adulthood. This more precise operationalisation of children of same-sex partners decreased their sample size $(\mathrm{N}=51)$ and, consequently, decreased the statistical power of the analyses. Nevertheless, the authors stressed that all methodological corrections they made were standard practice and that Regnerus should had made them as well in his analyses. Therefore, Cheng and Powell concluded that Regnerus' study did not offer credible evidence contradicting the existing consensus about lack of evidence suggesting differences in the outcomes of children who live with same- and opposite-sex partners.

The studies of Allen (2013) and Sullins (2015a, 2015b) also stated that their results indicated differences in harmful outcomes of children of same- and opposite-sex partners. Allen's study (2013) was conducted on a random sample of $20 \%$ respondents whose data were collected in the 2006 Canadian Census. Allen's article did not identify the exact sample size due to restrictions imposed by the data owner, Statistics Canada, although Allen suggested his analyses included more than 500 children. Sullins $(2015 a, 2015 b)$ used the data of the US National Health Interview Survey conducted on a random representative sample of American households, and aggregated for the period 1997-2013. Sullins' analyses included 512 children from households of same-sex partners. However, it is not entirely clear how many children total were involved in the analyses given that it appears that published articles contain an error regarding the sample size (one study specified that analysis included 195,240 children from 207,007 households, while the other claimed sample size of 207,007 children). Both Allen and Sullins used the problematic operationalisation of the category of children of same-sex parents. In both cases, this operationalisation was static and included all children who resided in a household of a same-sex couple at the moment of data collection. Therefore, although Allen and Sullins tended to suggest that their results spoke of outcomes of children raised by gays and lesbians, they could, in fact, speak only of children who, during a certain period of unknown duration, had constant contact with a 
same-sex couple or had gay or lesbian parents (Moore and Stambolis-Ruhstorfer, 2013).

The additional problem of Sullins' study of emotional difficulties (2015a) was the lack of equivalence between the family structures he compared. For instance, married and cohabiting same-sex partners were grouped together and were, as one category, compared to married and cohabiting opposite-sex partners grouped separately, in two categories. Therefore, for children included in the comparison, the differences in their parents' marital status were not taken into account. Also, Allen and Sullins' studies did not include the measures of stability of different family types which they compared, or the authors included them in a problematic manner. Sullins' study which analysed the differences in attention deficit hyperactivity disorder (ADHD) (2015b) did not use any measure of family stability, while his other study, which focused on serious emotional difficulties (2015a), used home ownership as a measure of family stability. That, for instance, the American Sociological Society (American Sociological Association, 2015) considers inappropriate, since home ownership cannot be a measure of family stability but only of socioeconomic status. Allen (2013) used two measures of family stability. In the main analyses, on which he based his conclusion of harmful educational outcomes (high school graduation), he measured the stability of a household by indicating whether the respondents had moved house in the previous year. However, in an additional analysis listed in the annex, but left out from his conclusion, Allen measured stability by indicating whether the household had moved in the previous five years. In this analysis he found no statistically significant differences in the outcomes for children of lesbian and gay couples and children of married opposite-sex parents. In Gates's opinion (2015), (not) moving in the previous year accounts for very short-term family transitions, while living in the same household for five years is a much more appropriate measure of family stability. Considering this finding, Gates stated that Allen's additional analysis contradicted what he claimed to find; it actually indicated that the stability of a household is more important for educational outcomes than whether children lived with a same- or opposite-sex couple.

Three other studies on random representative samples were published in the period observed in the present paper. Their comparisons of academic and psychosocial outcomes of children of same- and opposite-sex couples found no statistically significant differences (Potter, 2012; Potter and Potter, 2016, Bos et al., 2016, Bos, Kuyper and Gartrell, 2017) (Table 1). Each of these studies is methodologically distinctive and makes a unique contribution to understanding of homoparentality. 
Potter's study (Potter, 2012; Potter and Potter, 2016) is the only existing study of homoparentality based on a large random sample that analysed longitudinal data. The data used come from the US Early Childhood Longitudinal Study - the Kindergarten Cohort, the study which collected data on a random sample of children who went to a kindergarten in 1998. In the first publication based on these data, focused on academic achievements (Potter, 2012), the analysis included information about the children at five points in time (since kindergarten, when 19,107 were children included, up to the eighth grade when 8,342 children remained in the study). In the second publication, examining psychosocial wellbeing (Potter and Potter, 2016), the analysis included data at four points in time (since kindergarten, when 19,130 children were included in the analysis, up to the fifth grade, when 10,633 remained in the study). All the children who lived in the household of a same-sex couple during at least one wave of research were categorised as children from families of same-sex partners. A total of 158 such children was identified at all five points in time (Potter, 2012). In the first wave, the analysis included 72 children of same-sex couples, while in the fifth and eighth grade there were 22 of them left in the study. Therefore, despite starting from a large random sample, the initial analysed sample of children was relatively small, and further reduced by attrition in the subsequent waves of research. Also, like in numerous other studies of same-sex partners' families, most of the households examined were lesbian.

In addition, Potter's operationalisation of children of same-sex partners was rather wide and included children who resided in a household of a same-sex couple for only one year of the data collection, but not necessarily during the other years. Nevertheless, in each wave, the researchers collected data on the type of family structure. The researchers further conducted an inspection of every household identified as the household of a same-sex couple. The longitudinal research design allowed for tracking of child's "family transitions" over time, which, in turn, made it possible to use the measure of long-term family stability that was more precise than any used before. Both publications (Potter, 2012; Potter and Potter, 2016) emphasised how important was to control for family stability, since their results indicated that children from families characterised by stability were more likely to have better outcomes, regardless of their parents' sexual orientation or the type of family structure.

The study of Bos and collegues (2016) stands out as being the only study encompassing children growing up in a family of same-sex partners since birth. The authors used data from the US 2011-2012 National Survey of Children's Health that was based on a nationally representative sample of households with 
children. The study focused on stable couples, regardless of their marital status. They analysed same- and opposite-sex couples who were continually together and raising a child together since the child's birth. This condition ensured that family stability was kept constant. Nevertheless, the main limitation of the study is that the analysis excluded families with gay fathers due to the small number of such households meeting the requirements for participation. Therefore, the results on families of same-sex partners referred only to 95 lesbians' households. Still, this weakness was partially compensated for by the research design which matched the compared families by their characteristics, with the point of variation being parents' sexual orientation. The researchers randomly selected one household from the sample that included opposite-sex partners with the same characteristics of parents and children as each included lesbian household (Bos et al., 2016).

Finally, the most recent study comparing harmful outcomes of children from families of same- and opposite-sex partners on a nationally representative sample was the first study of the type conducted outside the Anglo-Saxon context. Bos, Kuyper and Gartrell (2017) used a random sample of Dutch households with children to identify 106 parents (47 women and 59 men) living in a household with their own child and a same-sex partner for at least two years. These families were then, based on certain characteristics of parents and children, matched with families of parents who raised their own child with an opposite-sex partner with whom they have been together for at least two years. This study also shared the limitation of many previous studies: the relatively small sample of children of same-sex partners. However, one particular advantage of this study is the inclusion of gay fathers who were usually underrepresented in such research. Also, the methodological strength of this study is matching-based sampling, which ensured that the compared families of same- and opposite-sex partners were truly equivalent. Finally, the study involved only couples who had neither divorced nor separated in the previous two years and who identified the child they were raising as their own (not being adopted, step- or a foster child; although the exact biological relationship to both parents was unknown). This condition ensured keeping family stability constant. The results of this latest Dutch study which, among other things, analysed the differences in psychological well-being of children of stable same- and opposite-sex couples were consistent with most other studies of homoparentality from the Anglo-Saxon context. They found no evidence of differences which might be attributed to the parents being same- or opposite-sex couple. 


\section{Discussion}

This paper systematically reviewed 15 studies conducted on large random samples that compared harmful outcomes of children from families of same- and oppositesex partners. The analysis focused on the following points of debate identified in the literature: the size of the sample of children from families of same-sex partners, the operationalisation of that category and inclusion of a control for family stability.

The main question related to the size of the sample of children of same-sex partners was whether the sample was large enough for reliable statistical analysis. The studies in the first wave of research (Wainright, Russell and Patterson, 2004; Wainright and Patterson, 2006, 2008; Fedewa and Clark, 2009) and the studies of the second wave which did not find statistically significant differences in children's outcomes (Potter, 2012; Cheng and Powell, 2015; Bos et al., 2016; Potter and Potter, 2016, Bos, Kuyper and Gartrell, 2017), with the exception of Rosenfeld's study (2010), all used samples with less than 200 children of same-sex partners. On the other hand, the studies of the second wave which identified statistically significant differences in harmful outcomes between children of same- and opposite-sex parents (Regnerus, 2012a; Allen, 2013; Allen, Pakaluk and Price, 2013; Sullins, 2015a, 2015b) included more than 500 children categorised as children from families of same-sex parents.

It is problematic to reduce the quality of a study to its sample size, even when speaking of quantitative studies. The key issue is what those numbers actually represent. If they do not represent the category of children raised by samesex couples, about which the conclusions are made, then these conclusions are necessarily invalid, even if the results were obtained through statistical tests of greater power that allow for a more precise generalisation. As I have shown in the analysis above, Regnerus', Allen's and Sullins' studies operationalised the category of children of same-sex partners in a too wide and/or static way and routinely included children who did not necessarily belong to that category. Therefore, those authors did not actually measure the outcomes of children raised in families of same-sex partners (American Sociological Association, 2015). It is inappropriate to increase the power of statistical tests by artificially expanding analysed categories. If, when the studies were conducted, it was not possible to identify children of same-sex partners in a more precise way or if there were still not enough such children in the population to reach the numbers necessary for a valid statistical analysis, then a better insight about these children's outcomes is offered by studies with a more valid operationalisation of the category. These may be qualitative studies that provide a deeper insight into the patterns of homoparentality, or 
quantitative studies which conduct an analysis of weaker statistical power, but compensate for the lack of power with other methodological and analytical procedures. For instance, analyses can include statistical corrections for small samples (e.g. statistical significance can be tested at the level of 10\%). Also, a particularly promising procedure is sampling which matches families of same- and opposite-sex partners by shared characteristics since this strategy allows for a better assessment of the effects of parents' sexual orientation on the children's outcomes (Wainright, Russell and Patterson, 2004; Wainright and Patterson, 2006, 2008; Bos et al., 2016; Bos, Kuyper and Gartrell, 2017).

The operationalization of the category of same-sex partners' children raised three issues. The first one has already been mentioned - a too wide definition of the category or its artificial expansion which then increased the statistical power of the analysis at the expense of representativeness of the category (see, for example, Regnerus, 2012a). The second problem, characteristic of the majority of the research, is a static definition of the category, i.e. including only children who, at the moment of data collection, lived with a same-sex couple, but were not necessarily raised by that couple. Such a methodological decision is often necessary for the feasibility of the study and does not pose an issue by itself. However, in such cases, the authors must be clear that, in their interpretation of the results, they cannot speak of children who were raised by same-sex couples. Only two of all analysed studies can truly interpret the outcomes of children growing up in households of same-sex partners. Those are Rosenfeld's study (2010), which included more than 3,000 children who resided in a household with a same-sex couple for at least five years, and the study by Bos et al. (2016), which was the first study including only children who lived with a same-sex couple since their birth. The third problem is limiting the category of children of same-sex partners only to children from lesbian households. This is also often the function of the feasibility of the study and the fact that the lesbian baby boom occurred about twenty years prior to gay couples first having the chance to become parents (Bos, Kuyper and Gartrell, 2017). Therefore, insights on the outcomes of children of same-sex partners are, indeed, mostly insights on the outcomes of children of lesbians. It is necessary to point out this limitation in the interpretation of the results. Nevertheless, studies such as Rosenfeld's (2010) and Bos, Kuyper and Gartrell's (2017) - which included children from gay households and which controlled for family stability in a satisfactory way - suggest that harmful outcomes of children of gays do not differ in a statistically significant way from outcomes of children of lesbians or partners of different sexual orientation. 
The final point of debate is omitting or inappropriately operationalizing an important control, that of family stability. This problem marks the studies of the first wave which did not identify statistically significant differences in harmful outcomes (Wainright, Russell and Patterson, 2004; Wainright and Patterson, 2006, 2008; Fedewa and Clark, 2009) and the studies of the second wave which did find those differences (Regnerus, 2012a; Allen, 2013; Allen et al., 2013; Sullins, 2015a, 2015b). Regardless of what is claimed in the conclusions, studies which did not include that measure in an appropriate way were not in a position to differentiate which of the identified differences in harmful outcomes were affected by parents' sexual orientation (which, in most cases, was not explicitly identified) and which were actually affected by possible family instabilities experienced by children of parents of homosexual orientation prior to living in the household of a same-sex couple (American Sociological Association, 2015). All analysed studies which controlled for family stability in an appropriate way, including Cheng and Powell's (2015) alternative analysis of data from Regenrus' study, did not find evidence of statistically significant differences in harmful outcomes of children from families of same- and opposite-sex partners. The same is true for studies with the best available controls for family stability so far - Rosenfeld's study (2010) which analysed only children who had lived in the same household for at least five years, Potter's longitudinal study (Potter, 2012; Potter and Potter, 2016) which included in the analysis the family transitions of children at multiple points in time, and the study by Bos and colleagues (2016) which included only children who had lived with a stable parental couple since birth.

\section{Conclusion}

The present paper provides an overview of all 15 quantitative studies based on random samples that have been published so far and that compared the harmful outcomes of children of same- and opposite-sex partners. In addition to including the most recent research of the type, the contribution of the present review is also a systematic and consistent comparison of these studies based on three main points of methodological debate identified in the literature. This analysis showed that the studies which questioned the consensus on the lack of evidence for harmful outcomes of children of same-sex partners (Regnerus, 2012a: Allen, 2013; Sullins, 2015a, 2015b) are marked by very serious methodological flaws. Therefore, based on these studies alone, it is not possible to make any conclusions about the outcomes of children growing up or being raised by same-sex partners. In contrast, even if we dismiss the findings of all other studies on homoparentality suffering 
from major or minor methodological flaws and if we look only at those studies that stand out exactly because of their methodological strengths (Rosenfeld, 2010) or because of a research design that enabled a unique contribution to the understanding of this topic (Potter, 2012; Potter and Potter, 2016; Bos et al., 2016), we see that their findings were consistent. They found no evidence of statistically significant differences in outcomes of children from families of same- and opposite-sex partners which could be attributed to the family structure in which those children were growing up.

The scientific relevance of this topic cannot be separated from its political relevance. The question of whether there is a consensus about the outcomes of children of same-sex partners has become a political weapon in the debate about the right of individuals of homosexual orientation to have children. Moreover, the politicization of this issue is exactly what informs the scientific debate about families of same-sex couples or LGBT individuals. As early as their 2001 article, Biblarz and Stacey noted how the debate was shaped by a defensive attitude from the majority of researchers who, fearing abuse of the results, tended to play down some differences they found between children of parents of homosexual and heterosexual orientation (e.g. in gender attitudes). In a value-free scientific discourse, the interpretation of these differences should focus on the fact that, as expected, there were differences - which were not necessarily better or worse between children raised in different family structures (Biblarz and Stacey, 2001). However, as the value-laden interpretations of some findings (e.g. an assumption that a homosexual orientation or a larger number of sexual partners is "a harmful outcome") had become a political tool, the researchers defensively highlighted only those results that pointed to the lack of differences in the outcomes that could be clearly identified as better or worse (e.g. academic achievement or psychological difficulties).

The consequence of such a defensive attitude is that the debate on homoparentality is shaped by the reaction to possible attacks by opponents of the right of same-sex couples and LGBT individuals to have children, instead of being shaped by the specific challenges that such families encounter. For instance, given the irrefutable evidence of how children from stable same-sex couples' families do not have poorer outcomes than children from other stable family structures, it appears that the debate is currently being directed towards discussing whether same-sex couples' families are more unstable than other family structures (see, for example, in Schumm, 2016). This debate focuses on whether the relationships of same-sex partners are more stable (mostly measured by the relationship duration) than the relationships of opposite-sex partners who have the choice to get married. 
Considering that the possible greater instability of same-sex relationships is attributed to, among other things, the institutional impossibility of getting married (Biblarz and Stacey, 2001; Schumm, 2016; Bos, Kuyper and Gartrell, 2017), such a focus is evidently hypocritical. Instead, the defensive attitude should be discarded and the research should focus on some specific problems experienced by families of same-sex couples and LGBT individuals. For example, the studies should examine the extent to which institutional inequalities and stigmatisations affect the outcomes of children from same-sex households. Such a shifting of the debate would raise awareness that levelling the playing field (social context) of all family forms is what increases the likelihood of a better outcome for all children.

\section{REFERENCES}

adams, jimi and Light, Ryan (2015). "Scientific consensus, the law, and same sex parenting outcomes", Social Science Research, 53: 300-310. doi: 10.1016/j.ssresearch.2015.06.008

Allen, Douglas W. (2013). "High school graduation rates among children of samesex households", Review of Economics of the Household, 11 (4): 635-658. doi: $10.1007 / \mathrm{s} 11150-013-9220-\mathrm{y}$

Allen, Doug (2015). "More Heat Than Light: A Critical Assessment of the SameSex Parenting Literature, 1995-2013", Marriage \& Family Review, 51 (2): 154-182. doi: 10.1080/01494929.2015.1033317

Allen, Douglas W., Pakaluk, Catherine and Price, Joseph (2013). "Nontraditional families and childhood progress through school: A comment on Rosenfeld", Demography, 50 (3): 955-961. doi: 10.1007/s13524-012-0169-x

Amato, Paul R. (2012). "The well-being of children with gay and lesbian parents", Social Science Research, 41 (4): 771-774. doi: 10.1016/j.ssresearch.2012.04.007

American Psychological Association (2005). Lesbian and Gay Parenting. http://www.apa.org/pi/lgbt/resources/parenting-full.pdf.

American Sociological Association (2015). Brief of Amicus Curiae American Sociological Association In Support Of Petitioners. http://www.asanet.org/sites/default/files/savvy/documents/ASA/pdfs/ASA_M arch_2015_Supreme_Court_Marriage_Equality_Amicus_Brief.pdf.

Barrett, Don (2012). "Presentation, politics, and editing: The Marks/Regnerus articles", Social Science Research, 41 (6): 1354-1356. doi: 10.1016/j.ssresearch.2012.08.010 
Biblarz, Timothy J. and Savci, Evren (2010). "Lesbian, Gay, Bisexual, and Transgender Families", Journal of Marriage and Family, 72 (3): 480-497. doi: $10.1111 / \mathrm{j} .1741-3737.2010 .00714 . \mathrm{x}$

Biblarz, Timothy J. and Stacey, Judith (2010). "How does the gender of parents matter?", Journal of Marriage and Family, 72 (1): 3-22. doi: 10.1111/j.17413737.2009.00678.x

Biblarz, Timothy J., Carroll, Megan and Burke, Nathaniel (2014). "Same-Sex Families", u: Judith Treas, Jacqueline Scott and Martin Richards (ur.). The Wiley Blackwell Companion to the Sociology of Families. Chichester: Wiley Blackwell, str. 109-131.

Bos, Henny M. W., Knox, Justin R., Van Rijn-van Gelderen, Loes and Gartrell, Nanette K. (2016). "Same-Sex and Different-Sex Parent Households and Child Health Outcomes: Findings from the National Survey of Children's Health", Journal of Developmental \& Behavioral Pediatrics, 37 (3): 179-187. doi: 10.1097/DBP.0000000000000288

Bos, Henny M. W., Kuyper, Lisette and Gartrell, Nanette K. (2017). "A Population-Based Comparison of Female and Male Same-Sex Parent and Different-Sex Parent Households", Family Process (In press). doi: 10.1111/famp. 12278

Cheng, Simon and Powell, Brian (2015). "Measurement, methods, and divergent patterns: Reassessing the effects of same-sex parents", Social Science Research, 52: 615-626. doi: 10.1016/j.ssresearch.2015.04.005

Eggebeen, David J. (2012). "What can we learn from studies of children raised by gay or lesbian parents?", Social Science Research, 41 (4): 775-778. doi: 10.1016/j.ssresearch.2012.04.008

Fedewa, Alicia L. and Clark, Teresa P. (2009). "Parent Practices and Home-School Partnerships: A Differential Effect for Children with Same-Sex Coupled Parents?", Journal of GLBT Family Studies, 5 (4): 312-339. doi: 10.1080/ 15504280903263736

Fedewa, Alicia L., Black, Whitney W. and Ahn, Soyeon (2015). "Children and Adolescents With Same-Gender Parents: A Meta-Analytic Approach in Assessing Outcomes", Journal of GLBT Family Studies, 11 (1): 1-34. doi: 10.1080/1550428x.2013.869486

Gates, Gary J. (2015). "Marriage and Family: LGBT Individuals and Same-Sex Couples", The Future of Children, 25 (2): 67-87.

Gates, Gary J. et al (2012). "Letter to the editors and advisory editors of Social Science Research", Social Science Research, 41 (6): 1350-1351. doi: 10.1016/j.ssresearch.2012.08.008 
Gobo, Giampietro (2008). "Re-Conceptualizing Generalization: Old issues in a New Frame", u: Pertti Alasuutari, Leonard Bickman and Julia Brannen (ur.). The SAGE Handbook of Social Research Methods. London: Sage, str. 193213. doi: 10.4135/9781446212165.n12

Golombok, Susan, Perry, Beth, Burston, Amanda, Murray, Clare, Mooney-Somers, Julie, Stevens, Madeleine and Golding, Jean (2003). "Children with lesbian parents: A community study", Developmental Psychology, 39 (1): 20-33. doi: 10.1037/0012-1649.39.1.20

Golombok, Susan and Badger, Shirlene (2010). "Children raised in mother-headed families from infancy: A follow-up of children of lesbian and single heterosexual mothers, at early adulthood", Human Reproduction, 25 (1): 150-157. doi: 10.1093/humrep/dep345

Jarić Dauenhauer, Nenad (2013). "Markić vara ljude lažnim istraživanjem!", tportal.hr. https://www.tportal.hr/tehno/clanak/markic-vara-ljude-laznimistrazivanjem-20131129.

Lubbe, Carien (2013). "LGBT Parents and Their Children: Non-Western Research and Perspectives", u: Abbie E. Goldberg and Katherine R. Allen (ur.). LGBTParent Families. New York: Springer, str. 209-223. doi: 10.1007/978-1-46144556-2_14

Manning, Wendy D., Fettro, Marshal Neal and Lamidi, Esther (2014). "Child WellBeing in Same-Sex Parent Families: Review of Research Prepared for American Sociological Association Amicus Brief', Population Research and Policy Review, 33 (4): 485-502. doi: 10.1007/s11113-014-9329-6

Marks, Loren (2012). "Same-sex parenting and children's outcomes: A closer examination of the American psychological association's brief on lesbian and gay parenting”, Social Science Research, 41 (4): 735-751. doi: 10.1016/j.ssresearch.2012.03.006

Moore, Mignon R. and Stambolis-Ruhstorfer, Michael (2013). "LGBT Sexuality and Families at the Start of the Twenty-First Century", Annual Review of Sociology, 39: 491-507. doi: 10.1146/annurev-soc-071312-145643

Osborne, Cynthia (2012). "Further comments on the papers by Marks and Regnerus", Social Science Research, 41 (4): 779-783. doi: 10.1016/j.ssresearch.2012.05.002

Perrin, Andrew J., Cohen, Philip N. and Caren, Neal (2013). "Are Children of Parents Who Had Same-Sex Relationships Disadvantaged? A Scientific Evaluation of the No-Differences Hypothesis", Journal of Gay \& Lesbian Mental Health, 17 (3): 327-336. doi: 10.1080/19359705.2013.772553 
Potter, Daniel (2012). "Same-Sex Parent Families and Children's Academic Achievement", Journal of Marriage and Family, 74 (3): 556-571. doi: 10.1111/j.1741-3737.2012.00966.x

Potter, Daniel and Potter, Emma C. (2016). "Psychosocial Well-Being in Children of Same-Sex Parents: A Longitudinal Analysis of Familial Transitions", Journal of Family Issues (In press). doi: 10.1177/0192513X16646338

Powell, Brian, Hamilton, Laura, Manago, Bianca and Cheng, Simon (2016). "Implications of changing family forms for children", Annual Review of Sociology, 42: 301-322. doi: 10.1146/annurev-soc-081715-074444

Regnerus, Mark (2012a). "How different are the adult children of parents who have same-sex relationships? Findings from the New Family Structures Study", Social Science Research, 41 (4): 752-770. doi: 10.1016/ j.ssresearch.2012.03.009

Regnerus, Mark (2012b). "Parental same-sex relationships, family instability, and subsequent life outcomes for adult children: Answering critics of the new family structures study with additional analyses", Social Science Research, 41 (6): 1367-1377. doi: 10.1016/j.ssresearch.2012.08.015

Rosenfeld, Michael J. (2010). "Nontraditional families and childhood progress through school", Demography, 47 (3): 755-775. doi: 10.1353/dem.0.0112

Rosenfeld, Michael J. (2013). "Reply to Allen et al.", Demography, 50 (3): 963969. doi: 10.1007/s13524-012-0170-4

Schumm, Walter R. (2016). "A Review and Critique of Research on Same-Sex Parenting and Adoption", Psychological Reports, 119 (3): 641-760. doi: $10.1177 / 0033294116665594$

Stacey, Judith and Biblarz, Timothy J. (2001). “(How) Does the Sexual Orientation of Parents Matter?", American Sociological Review, 66 (2): 159-183. doi: $10.2307 / 2657413$

Sullins, Donald Paul (2015a). "Emotional Problems among Children with SameSex Parents: Difference by Definition", British Journal of Education, Society and Behavioural Science, 7 (2): 99-120. doi: 10.2139/ssrn.2500537

Sullins, Paul D. (2015b). "Child Attention-Deficit Hyperactivity Disorderv (ADHD) in Same-Sex Parent Families in the United States: Prevalence and Comorbidities", British Journal of Medicine \& Medical Research, 6 (10): 987-998. doi: 10.9734/BJMMR/2015/15897

Tasker, Fiona L. and Golombok, Susan (1997). Growing up in a Lesbian Family: Effects on Child Development. New York: Guilford Press.

Vanfraussen, Katrien, Ponjaert-Kristoffersen, Ingrid and Brewaeys, Anne (2003). "Family functioning in lesbian families created by donor insemination", 
American Journal of Orthopsychiatry, 73 (1): 78-90. doi: 10.1037/00029432.73.1.78

Van Rijn-van Gelderen, Loes, Bos, Henny M. W. and Gartrell, Nannete K. (2015). "Dutch adolescents from lesbian-parent families: How do they compare to peers with heterosexual parents and what is the impact of homophobic stigmatization?", Journal of Adolescence, 40: 65-73. doi: 10.1016/ j.adolescence.2015.01.005

Wainright, Jennifer L., Russell, Stephen T. and Patterson, Charlotte J. (2004). "Psychosocial adjustment, school outcomes, and romantic relationships of adolescents with same-sex parents", Child Development, 75 (6): 1886-1898. doi: 10.1111/j.1467-8624.2004.00823.x

Wainright, Jennifer L. and Patterson, Charlotte J. (2006). "Delinquency, victimization, and substance use among adolescents with female same-sex parents", Journal of Family Psychology, 20 (3): 526-530. doi: 10.1037/08933200.20.3.526

Wainright, Jennifer L. and Patterson, Charlotte J. (2008). "Peer relations among adolescents with female same-sex parents", Developmental Psychology, 44 (1): 117-126. doi: 10.1037/0012-1649.44.1.117 


\title{
Usporedba ishoda djece iz obitelji istospolnih $\mathbf{i}$ raznospolnih partnera: osvrt na kvantitativne studije provedene na slučajnim reprezentativnim uzorcima
}

\author{
Tanja VUČKOVIĆ JUROŠ \\ Interdisciplinarni istraživački centar za obitelj i seksualnost (CIRFASE), Katoličko \\ sveučilište u Louvainu, Louvain-la-Neuve, Belgija \\ tanja.vuckovic@uclouvain.be
}

Većina istraživanja homoparentalnosti, koja su se počela provoditi krajem sedamdesetih i početkom osamdesetih godina 20. stoljeća u anglosaksonskom kontekstu, nije našla dokaza o štetnim ishodima djece lezbijki i gejeva koji bi bili posljedica seksualne orijentacije njihovih roditelja. Te su studije tipično bile ograničene malim uzorcima i uključivanjem samo obitelji lezbijki. Početkom 21. stoljeća počele su se provoditi kvantitativne studije koje uspoređuju ishode djece istospolnih i raznospolnih partnera na temelju slučajnih reprezentativnih uzoraka. Ovaj se rad sustavno osvrće na ta istraživanja, pri čemu se analiza fokusirala na trima točkama metodoloških prijepora koje su identificirane u literaturi $\mathrm{o}$ homoparentalnosti: karakteristike uzorka, pitanje operacionalizacije kategorije djece istospolnih parova i uključivanje kontrolne varijable obiteljske stabilnosti. Rezultati većine studija provedenih na slučajnim reprezentativnim uzorcima sukladni su nalazima prijašnjih istraživanja. Manjinu takvih studija koje nalaze neke statistički značajne razlike u štetnim ishodima djece obilježavaju ozbiljne metodološke zamjerke poput umjetnog povećavanja kategorije djece iz obitelji lezbijki i gejeva (primjerice, uključivanjem djece koja moguće ili vjerojatno nikad nisu odrastala u obitelji istospolnog para) i izostanka kontrolne varijable za obiteljsku stabilnost u analizama. Stoga se u ovom osvrtu zaključuje da znanstveno najkredibilnije kvantitativne studije provedene na slučajnim reprezentativnim uzorcima pružaju snažnu potporu zaključku mnoštva ranijih kvalitativnih i kvantitativnih studija provedenih na prigodnim uzorcima - nema uvjerljivih dokaza o razlikama u štetnim ishodima djece koju odgajaju istospolni i raznospolni partneri koje bi se mogle pripisati seksualnoj orijentaciji roditelja.

Ključne riječi: djeca, dobrobit djece, štetni ishodi odgoja, obitelj, istospolni partneri, raznospolni partneri, homoparentalnost 